\title{
Making the Call: Art and Politics in Ronald Harwood's Taking Sides
}

\author{
Ann C. Hall \\ Department of Comparative Humanities, University of Louisville, Louisville, KY 40292, USA; \\ Ann.hall@louisville.edu
}

Received: 4 September 2020; Accepted: 8 October 2020; Published: 13 October 2020

\begin{abstract}
Set in Germany during the denazification processes following World War Two, Ronald Harwood's Taking Sides (1995 play, 2001 film) pits German conductor Wilhelm Furtwängler against a relatively uncultured American interrogator, Steve Arnold, to, as Harwood says, examine the role of an artist under a totalitarian state and an American's mistreatment of the world-renowned maestro. While there is certainly a contrast between the old world, represented by the classical music of Furtwängler, and the new, represented by Arnold's affinity for jazz, there is much more at stake in both the play and the film. As the interrogation progresses, Arnold, who worked as an insurance claims adjuster during his civilian days, senses Furtwängler's arguments about art as apolitical, are what he calls "airy-fairy" excuses. Arnold knows Hitler favored Furtwängler, used his music to inspire his atrocities, and gave Furtwangler access to almost anything he wanted. Critics frequently praise the play and film for its balanced presentation of the two sides. However, by examining the play and the film in terms of Aristotelian tragedy, this essay makes clear that Furtwängler's refusal to take sides has grave consequences, consequences that only the crude, "ugly American" Arnold is willing to discuss.
\end{abstract}

Keywords: Ronald Harwood; Taking Sides; denazification; Wilhelm Furtwängler; Jewish Drama

Ronald Harwood's Taking Sides (1995 play; 2001 film) dramatizes an interrogation between the famous German conductor, Wilhelm Furtwängler, and an American, Major Steve Arnold, as part of the denazification procedures following the Second World War. Both the play and film present an array of opposing viewpoints and perspectives. They explore the dualities of art and politics; the individual and totalitarianism; and the European traditions and the new, American culture. Even Harwood's motivations for writing are bifurcated. He admits he wanted to write about Furtwängler to investigate the role of the artist in a totalitarian state (Harwood 1995a, p. xi), as well as explore the Americans' poor treatment of the maestro (Harwood 1995b, p. 3). The contrasts continue in the film version directed by István Szabó, with a screenplay by Harwood. Szabó expands the mise en scène to juxtapose the architecture of pre-war and Nazi Germany against the destruction of the war. For many critics of the play and film, Harwood does a masterful job presenting the case for both sides of the art and politics divide. ${ }^{1}$ The play presents both Furtwängler's commitment to art and its power and Arnold's commitment to justice and reparation for the millions of Jews murdered during the Holocaust. For Harwood, the lack of an "up-ending," as he calls it, creates a tragedy. But by examining Taking Sides

1 Vincent Canby describes the balance in the play: "The philistines don't come off well here, but neither does the artist"; there are "no easy answers" (Canby 1996). John Cunningham says, "Ultimately the film, like the play on which it is based, provides no answers to the question as to which side one should take and the viewer has to make up his or her own mind" (Cunningham 2014, p. 114). John Gardiner concurs: “Just as in Harwood's original play, Szabó's film deliberately does not take sides" (Gardiner 2010, p. 97). For an opposing viewpoint, see Victoria Stewart who argues that "the argument is won by Furtwängler from the very beginning" (Stewart 2000, p. 7). 
from an Aristotelian tragedy's perspective, the ambivalent ending is not without meaning. We learn that by not taking sides, as Furtwängler attempted, decisions are made, and consequences occur.

Tragedy and World War Two dominate Harwood's life. Born in Cape Town, South Africa in 1934, as Ronald Horowitz, Harwood followed his heart's desire and came to London in 1951 to study at the Royal Academy of Dramatic Arts (RADA). He changed his name because, he says, it was common practice at the time (Robinson 2017, p. 17); not, as many assume, to disguise his Jewish faith, culture, and heritage. Quoting Joseph Roth, Harwood remarks: "Jews, Eastern Jews, have no names. They have compulsory aliases. Their true name is the one by which they are summoned to the Torah on the Sabbath and on holy days: their Jewish first name, and the Jewish first name of their father" (Robinson 2017, p. 17). Having left RADA, Harwood worked with Sir Donald Wolfit, one of the last great actor-managers, for many years. ${ }^{2}$ Wolfit was known for his Shakespearean performances, so Harwood learned the tragic structure early in his career. He was famous for his King Lear, which he performed during the bombings of London at a time when other theatrical organizations were closed. Harwood memorialized the event in his play and film, The Dresser (Harwood 1980, 1983).

Harwood admits that "the war defined my childhood, the Holocaust my adolescence. That synthesis has dominated much of my creative life ever since" (Robinson 2017, p. 7). He recalls a time in 1945 when he and "other Jewish schoolchildren" were taken to see the newsreels of "Belsen and Auschwitz. Those dreadful images—the skeletons passing for human beings, the bulldozers shining mounds of corpses into mass graves-have haunted me ever since" (Robinson 2017, p. 7). His canon of work attests to this fact. Harwood won an Oscar in 2003 for his screenplay of The Pianist, and received the American National Jewish Theatre Foundation Lifetime Achievement Award in 2014.

Harwood references Aristotle in his works when he says his films, particularly, avoid the "feel good" endings of so many American movies because he wants to present "a genuine tragic experience" (Harwood 2005, p. 11). For Aristotle, and simply put, tragedy presents a fall from prestige, power, and influence due to a miscalculation on the part of the hero, hamartia. Through the reversal of fortune, peripetia, a recognition, anagnorisis, should occur (Aristotle 1981, pp. 23-29), and this process affects the audience, creating what Aristotle calls catharsis.

Tragedy, of course, is much more complicated, and the discussions of tragedy have created their own cottage industry of criticism across historical periods and cultures. In more modern times, George Steiner argues that given modern and postmodern cultures, tragedy cannot occur. The era that gave birth to tragedy presumed specific cultural, religious, and social characteristics, characteristics that are no longer in place. Rita Felski, however, counters, saying Steiner's thesis:

may clarify why traditional tragedies are no longer written, but it cannot explain why they are still being read, watched, performed, revised, and invoked .... From the standpoint of a strong historicism, tragedy could only be of antiquarian interest, a musty cultural relic as remote from the concerns of modernity as humors or physiognomy. That this does not seem to be the case suggests that we need to acknowledge generic continuity as well as generic change. (Felski 2008, p. 14)

Helen P. Foley and Jean E. Howard concur, "tragedy is not dead," adding "old forms of it are repurposed for new occasions, and new forms of it are constantly invented under the pressure of historical circumstance ... its meaning will change as the contexts change" (Foley and Howard 2014, pp. 619-20). Other tragic commentators argue similarly: the tragic genre is not prescriptive nor static. ${ }^{3}$ Foley and Howard rightly note that even Aristotle is unclear, particularly regarding catharsis, the effect tragedy has upon audiences (Foley and Howard 2014, pp. 621-22).

2 Harwood and Pinter both worked with Wolfit. John Osborne auditioned, but was not "taken on by Wolfit" (Robinson 2017, p. 32).

3 See, for example, Bushnell (2005), Eagleton (2003), Felski (2008), and Wallace (2007) for extensive discussion on the development of tragedy and its various permutations through history and culture. 
Some boundaries, however, must exist to determine whether or not a work upholds tragic expectations or, at least, approximates tragedy. Robert Heilman makes the distinction between "disaster," which results in victimization, and "tragedy" during which a flawed human "faces basic conflicts, perhaps rationally insoluble, between obligations, and among obligations and passions ... He undergoes the consequences of his choice, and in suffering achieves a new or renewed awareness of his action and himself and the order of life" (Heilman 1968, p. 19). But as Foley and Howard point out, not all tragic heroes "achieve recognition ... yet tragedies still invite audiences to confront, and depart with a changed or enlarged perspective on, human suffering and the human ability to understand, control, and make predictions about the world" (Foley and Howard 2014, p. 621).

Felski perhaps offers the most comprehensive description of tragedy and succinct definition of tragedy: they depict characters who exhibit "miscalculated confidence and its consequences" (Felski 2008 , p. 2). Their hubris leads to error; they suffer the consequences; but there is no simple moral to the story, no "unambiguous role in the Manichean struggle of good versus evil, virtue versus vice" (Felski 2008, p. 7). Tragedy revels in ambiguity: "Tragedy is prized for its refusal to offer clear-cut solutions and absolute judgments" (Felski 2008, p. 7).

In the case of Taking Sides, both the play and film share the same dramatic structure: a hero's fall from grace. As the play progresses, however, it is almost as if Harwood has split the tragic hero into two. Furtwängler falls from grace but remains blind, denying any significant error. Rather than merely serving as an ugly American, Arnold exhibits the investigative power of Oedipus and finds the truth about Furtwängler. The audience is left to mete out punishment.

Harwood based the play on Berlin Days by George Clare, which was based on Clare's own experiences with the denazification process following World War II: "His first assignment was to put together a file on the maestro of Hitler's Germany: Dr. Wilhelm Furtwängler ... His findings were at once clear and ambiguous" (Robinson 2017, p. 174). Furtwängler had participated in Nazi events, but he had also helped "Jewish musicians escape from persecution" (Robinson 2017, p. 174). Clare could not decide. Furtwängler claimed that he was resisting the Nazis through his work, but as Clare says, "compromising with evil to prevent worse ... is always futile, but to know this after the event was as easy as ... it is difficult to recognize malignancy in infancy" (qtd. In Robinson 2017, p. 174).

Creating art under the Nazis may be impossible. As Michael Kater observes, "the aesthetic, formal, and ethical power of culture thrives on contradiction to prevailing social and political norms, or even the exposition of unresolved tensions, then it will arguably always fail under tyranny"(Kater 2019, p. 22). In the case of the Nazis, culture and genetic purity united. The use of art and culture, combined with the concept of Jews as genetically flawed or "polluted", resulted in what Hannah Arendt called the "banality of evil" (Etlin 2002, p. 27). The Nazi's "biologically racialist worldview" denigrated Jewish humanity "through a supposed inability to contribute to culture" (Etlin 2002, pp. 22-23). Only pure Germans could create art, particularly music (Dumling 2002, p. 53), with composers Bach, Beethoven, and Bruckner favored. The Third Reich had a concerted effort "to create a National Socialist aesthetic" (Kater 2019, p. 22). Artists responded in various ways. Some left or escaped. Some would have succeeded under any regime. Some compromised. And there were those whose work suffered under the regime (Kater 2019, pp. 241-45). For Kater, Furtwängler was "an opportunistic servant of all regimes" (Kater 2019, p. 257).

Taking Sides opens with Major Arnold trying to figure out how opportunistic the conductor is. The play presents Arnold as a philistine, the consummate ugly American. ${ }^{4}$ Emmi, his German secretary, tries to introduce him to classical music, particularly the pieces conducted by Furtwängler. Arnold not only sleeps through the maestro's version of Beethoven's Fifth, when Emmi asks him to explain, he also answers, crudely, "because Beethoven's Fifth Symphony bores me shitless" (Harwood 1995b, p. 8).

4 In a document in the Harwood archives at the British Library, MS88881/1/56, Harwood notes that when Pinter directed the play, he portrayed Arnold as a philistine to make Furtwängler's defense more appealing. Stanley Kauffmann thought the major a "cartoon" in the play (Kauffman 2003). 
The film underscores Arnold's cultural ignorance. While Arnold, an insurance man before the war, has heard of Arturo Toscanini, General Wallace resorts to American pop culture to describe Furtwängler's celebrity status in Germany and Europe: they say "he's probably Bob Hope and Betty Grable rolled into one" (Harwood 2002, p. 123). The references highlight the differences between the old and new world cultures. But even Arnold's appreciation of the new American art form, jazz, is not particularly nuanced. He compliments a saxophone player in the following way: "not bad. Not good, but not bad. Played one-night stands in Illinois and Michigan" (Harwood 1995b, p. 8).

To complicate matters further, Arnold makes anti-Semitic remarks. When he mentions that he caught the sax player mentioned earlier in an insurance scam - the musician set fire to his own house-he describes the fraud as "Jewish lighting." Initially, Arnold appears a "vulgarian," a representative of American sentiments regarding German culture, a culture that presumed itself to be the best representation of high art, a presumption that many felt "could explain how Nazism had arisen and flourished" (Gardiner 2010, p. 104). While his staff, both Jews and non-Jews, defer to Furtwängler and think Germany the greatest musical country, Arnold calls the maestro a "band leader."

This inauspicious representation of Arnold invites us to underestimate him, but this characterization does not persist. What Arnold lacks in musical education, culture, and etiquette, he makes up for in instinct and tenacity. He does not suffer fools, and though he participates in the military hierarchy, he resists formal titles and asks his staff to use first names only, dispensing with formalities. In the film, his superiors call him "conscientious, determined, dogged" (Harwood 2002, p. 122). He has an uncanny memory and a secret to his successes as a civilian insurance claims assessor, a method that cannot be taught or learned, like music and culture - there is "always one question the guilty can't answer" (Harwood 1995b, p. 8). Arnold's love of jazz, moreover, does not merely indicate his cultural ignorance. As Michael Kater shows, "the Nazis hated jazz" (Kater 2019, p. 237). It represented new, modern forms, not the traditional Aryan art forms the Nazis preferred and promoted. Arnold may appear uncultured, but there is more to his character; he represents a threat to the Nazi aesthetic as well.

In the film, Arnold's complex characterization is simplified to a degree. His advisors, for example, tell him that the conductor is guilty. Arnold's job is to find evidence to prove the case. In the play, however, Arnold has more agency. Arnold, however, gradually uncovers the truth about the maestro using his instincts and his experience, not military information or education.

At the opening of the play, we learn that Arnold has interrogated twenty-eight orchestra members, and every one of them admits to the following: they revere Furtwängler. They deny any allegiance to the Nazis. They admire Arnold's assistant Emmi's father, who fought against the Nazis. All tell an apocryphal "baton story."

According to all the witnesses, the "baton story" proves Furtwängler's resistance to the Nazis. Furtwängler performs for Hitler, but he does not want to offer the Nazi salute; instead, he holds the baton in one hand and shakes Hilter's hand with his other. For all orchestra members, this image and moment prove Furtwängler's anti-Nazi stance. While interviewing Mr. Rode, one of the witnesses, Arnold is exasperated by the "baton story," concluding, "what they're trying to do is cover the band leader in roses in the hope they'll come up smelling just as sweet. But it's difficult to smell sweet after you've crawled through the raw sewage" (Harwood 1995b, p. 12).

Arnold's other assistant, David, is German-Jewish. While the Nazis killed both of his parents, he, too, lionizes the conductor and seeks "hard evidence" against him, not just insinuation or rumor. The play seems to support David's perspective. Following the interview with Rode and right before the interview with Furtwängler, a distraught woman enters. She claims that she has a list of people, mostly Jews, whom Furtwängler helped escape. According to her, he helped her German-Jewish husband escape to Paris. She was not Jewish, so she remained in Germany. Her husband was later caught and murdered in Auschwitz. She adds, "that's in Poland," as if Arnold were too ill-informed, perhaps too American, to know what she is referring to (Harwood 1995b, p. 23). 
David interprets this news as evidence for the defense, but Arnold remains unconvinced. Not only are the stories too convenient, too similar, but he also tells David about an incident he had with a taxi driver. As he and the driver made their way through Berlin, Arnold said, "to think, a million of these people came out to welcome Adolf on the day he entered the city, millions of them, and now look at 'em." To which the taxi driver replied, "Oh, not these people, Major. These people were all at home hiding Jews in their attics" (Harwood 1995b, p. 25). To make sure David does not miss the message of the story, Arnold says, "The point is they're [Germans] full of shit" (Harwood 1995b, p. 25). All walked through the sewage, and all were responsible.

In the film, the U.S. military indoctrinates American soldiers against the Germans. They are warned through film, radio, and posters not to fraternize with Germans: "In a German town, if you bow to a pretty girl or pat a blond child, you bow to all that Hitler stood for. You bow to his reign of blood. You caress the ideology that meant death and destruction. You never know who was a member of the Nazi Party" (Harwood 2002, p. 125). In the play, because Arnold comes to the conclusion on his own, without the help of American or British propaganda, the point is more powerful. He intuits ethical transgressions. His conscience leads him, not post-war propaganda. John Cunningham compares him to Edward G. Robinson in Double Indemnity, the insurance man who ferrets out evil and corruption (Cunningham 2014, p. 110). Arnold, then, may be ignorant or uninterested in high art, but he is a man with a conscience. Arnold uses his civilian tactics while interviewing Furtwängler. He makes the conductor wait before starting, asks him innocuous questions, and encourages him to confess. Furtwängler, however, is a formidable foe. He does not volunteer information, as the others have. Frustrated, Arnold cries out, “Jesus Christ, aren't you going to tell us about carrying your baton in your right hand so you wouldn't have to salute and poke Adolf's eyes out?" (Harwood 1995b, p. 27).

After a few more questions and details, it appears that Arnold's intuition is correct. We learn Furtwängler worked with the Nazis, and a mere handshake or lack of salute offers slim evidence for his defense. Furtwängler's perspective, however, complicates this easy conclusion. He explains that since he is an artist: "I have always held the view that art and politics should have nothing to do with one another" (Harwood 1995b, p. 29). He claims that he wrote against the Nazis because they were destroying music. Their racial cleansing gutted orchestras (Harwood 1995b, p. 32). He says he was tricked, oppressed, in constant danger, but he remained in Germany for altruistic reasons: "I remained here to give comfort, to see that the glorious musical tradition, of which I believe I am one of the guardians, remained unbroken, was intact when we woke from the nightmare" (Harwood 1995b, p. 33). Even David confirms this outcome. Although Furtwängler worked with the Nazis, David proclaims: "ever since I heard you, music has been central to my life. My chief comfort. And I've needed comfort. I thank you for that" (Harwood 1995b, p. 35).

For Arnold, who is not star-struck, such answers are examples of "airy- fairy bullshit" (Harwood 1995b, p. 33). He points out that this noble resistance was really nothing. Furtwängler wrote against the Nazis when his music was affected, not to denounce the murder of millions of European Jews. Furtwängler's defense is flimsy.

But as the second act illustrates, that while finding anything substantial against the conductor is challenging, it appears that Arnold's instincts are correct. The act opens with the revelation that Rode, the second violinist, who said he was not a Nazi, never could be one, and never would be one, was not only a Nazi but "their man in the orchestra" (Harwood 1995b, p. 39). Rode defends himself using the Nazi milieu:

absolute power offers absolute certainty and absolute hope... You start by censoring what you say, then you censor what you think, and you end by censoring what you feel. That is the greatest degradation because it means the entire individual will is paralyzed, and all that remains is an obedient husk. (Harwood 1995b, p. 9)

The speech not only highlights the corrosiveness and perniciousness of totalitarianism, but it prompts Rode to conclude that Furtwängler's methods were similar to Hitler's, further sullying the 
conductor's reputation. Rode discusses how intimidating the conductor could be, and we later learn about his promiscuous habits, procuring and using women as pre-performance inspiration (Harwood 1995b, pp. 57-58). Most importantly, while we begin to understand Rode's situation in Nazi Germany, he admits that he would have never made second violin without the removal of Jewish musicians. Again, while there was pressure and the situation under the Nazis was dire for non-Jewish Germans, Rode's story illustrates that there was also personal culpability. Greed and ambition fed into his decision to remain in the orchestra. With the Jewish performers out of the way he, and others like him, could take their place.

Provoked by Arnold's discovery of his Nazi past, Rode tries to come up with evidence against Furtwängler, but it remains inconclusive. He may have sent one of his critics to the Russian front and made anti-Semitic remarks. David dismisses such evidence: "Show me a non-Jew who hasn't made anti-Semitic remarks and I'll show you the gates of paradise" (Harwood 1995b, p. 49).

So with a German-Jewish staff member supporting his foe, the play suggests that Arnold's final confrontation with Furtwängler is based on a hunch. He asks Emmi to play a recording of Bruckner's Seventh, the "slow movement" (p. 43), when he gives the signal. ${ }^{5}$ Delighted, Emmi thinks she has finally transformed Arnold into a classical music listener, but as we will see in the final scenes, the music serves as a soundtrack for the final battle between Furtwängler and Arnold. The Bruckner piece was played across Germany to mourn Hitler's suicide, and the version was Furtwängler's.

During the final interview, Furtwängler defends himself based on art. He explains that it is "my religion" (Harwood 1995b, p. 50). He admits that he may have been naive, but he thought his work would create something practical: "the maintenance of liberty, humanity, and justice" (Harwood 1995b, p. 51). In the totalitarian milieu, art offered hope:

I know that a single performance of a great masterpiece was a stronger and more vital negation of the spirit of Buchenwald and Auschwitz than words. Human beings are free wherever Wagner and Beethoven are played. Music transported them to regions where torturers and murderers could do them no harm. (Harwood 1995b, p. 63)

Such an argument is compelling, particularly for theatre and film audiences who, by their participation in both art forms, appreciate the power of art on some level. But Furtwängler does not admit any error, with the possible exception of being naive. He has experienced the tragic fall (peripeteia), but he has not experienced the tragic recognition (anagnorisis). Moreover, he continues to deny and excuse his relationship to the Nazis.

As in the case of Rode, Arnold proposes a human, practical, and selfish motive:

I don't see a great artist ... I see a man, an ordinary guy, like a million other ordinary guys. And I ask myself, what keeps him in a situation which he says he did everything in his power to resist, except get the hell out of it? What keeps him here ... I look for ordinary reasons. (Harwood 1995b, p. 57)

Arnold claims that the threats the Nazis made towards Furtwängler were not censorship or torture, but competition in the form of a younger conductor, Herbert Van Karajan:

Never mind art and politics and symbols and airy-fairy bullshit about liberty, humanity and justice. You were tricked all right because they got you where you were most vulnerable. Youth was knocking on the door, and I don't care how great you are, how noble, how fantastic ... because it's the oldest story in the book. (Harwood 1995b, p. 54)

Like Rode, Furtwängler denies the simple conclusion and blames the Nazi reign of terror:

5 In the film, he uses the word, "Adagio" (Harwood 2002). The change is significant because it suggests that Arnold may have more musical knowledge than he reveals to his staff and the maestro. 
They controlled the press. Every word that was written, every word that was published. When I resigned from the Philharmonic, when I refused to take part in a film they made about the orchestra ... they were determined to keep me in my place ... They controlled every aspect of our lives. They manipulated, bullied and imposed their monstrous will. When they finally understood that I would do everything in my power to prevent art from being directed and supervised, they determined to undermine me. They regarded any action of dissent, however small, as a criticism of the state, tantamount to high treason. (Harwood 1995b, p. 56)

The conductor's defense begins to falter. He argues that he was protecting his art, offering it to the German people as cultural and emotional sustenance. Further, he was taking his work to new levels of perfection, levels that a conductor he considers too "intellectual," like von Karajan, could not (Harwood 1995b, p. 56). The play, however, undercuts his characterization of von Karajan. It seems petty, forced, and a personal assessment to dismiss a conductor who was his competitor. Furtwängler admits no responsibility; he only defends himself in terms of his art. His dismissal of von Karajan highlights his detachment the Holocaust's realities and his commitment to his own personal gain.

Arnold reminds him:

Have you ever smelled burning flesh? I smelt it four miles away. Four miles away, I smell it. I smell it now, I smell it at night because I can't sleep any more with the stench of it in my nostrils. I'll smell it for the rest of my life. Have you seen the crematoria and the gas ovens? Have you seen the mounds of rotting corpses being shovelled into gigantic craters by the men and women who murdered them? ... Yes, I blame you for not getting hanged, I blame you for your cowardice. You strutted and swaggered, king-pin in a shithouse. (Harwood 1995b, p. 64)

Even after this speech, Furtwängler does not relent. He proclaims that to live without art, to live only in the "material world," will leave the future "more foul-smelling than that which pervades your night" (Harwood 1995b, p. 65).

For Furtwängler, his sacrifice was working with the Nazis to continue his art. For Arnold, Furtwängler's sacrifice was the murder of European Jews to work with the Nazis who supported his art. He profited from their favor: "You were their boy, their creature. That's the case against you, old pal. You were like an advertising slogan for them .... You may not have been a member of the Party because the truth is, Wilhelm, you didn't need to be" (Harwood 1995b, p. 62). Furtwängler was a de facto Nazi. He profited from Nazi favor: "When the Devil died they wanted his band leader to play the funeral march" (Harwood 1995b, p. 63).

John Gardiner argues that the two sides presented in the play are "compelling, but they operate on totally different planes and can never be completely reconciled. The moral world of Taking Sides is at its deepest and starkest here" (Gardiner 2010, p. 105). He suggests leaving the question unanswered may be the best conclusion. Early in his essay, however, Gardiner mentions that one of the problems with Furtwängler is that he did not "take sides." He characterizes the conductor as "not only an opposite but a void or absence" (Gardiner 2010, p. 99). Too focused on his art and his own ego, he does little to resist, little to speak out. And what resistance he makes is almost invisible.

Further, despite Furtwängler's compelling arguments about art, transcendence, liberty, and freedom, the Nazis used his music, not to free others but to inspire others to imprison, torture, and kill. Szabó's film highlights this during many of the live performances offered in the film. While Furtwängler's music comforted and sustained Germans, both Jews and non-Jews, his music was the music of Hitler's Germany. It fueled and inspired the Nazis. The fact that the Germans played Furtwängler's version of Bruckner at Hitler's death, and that music continued throughout the atrocities of the Third Reich, suggest the scope of Furtwängler's influence in Nazi Germany. Szabó's film highlights the Nazi's use of music and propaganda from the start: "It [the film's opening] is a powerful 
moment, intensified and extended by Szabó's direction where a long majestic tracking shot slowly reveals the nature of the audience (many of who are uniformed SS)" (Cunningham 2014, p. 114). And while Furtwängler is not entirely responsible for this use, he bears some culpability, notably since he not only remained in Germany but profited from the Nazi regime.

At the end of the play and film, Arnold realizes that he cannot find "hard evidence" against Furtwängler. In the play, he calls a "tame journalist" who will help give Furtwängler a "hard time" (Harwood 1995b, p. 66). In the film, through a voice-over, Arnold says, "I didn't nail him. But I sure winged him. And I know I did the right thing" (Harwood 2002, p. 195). Both the play and film complicate our understanding of Arnold who has, up until now, seemed to be driven by the pursuit of justice on an intuitive level. But his connection to the journalist may prompt us to challenge his integrity. Is he behaving like Hitler, manipulating the media to his own ends? Does the play, once again, complicate our ability to "take sides" by questioning Arnold's methods?

István Szabó suggests an interpretation by concluding the film with some archival footage of Furtwängler shaking hands with Joseph Goebbels. Again, the conductor does not offer the salute, but instead, shakes his hands. The camera offers a close-up of Furtwängler, apparently wiping his hands: "The film replays this gesture several times-Furtwängler wiping his hands" (Harwood 2002, p. 195). On the one hand, the image suggests that Furtwängler is "wiping his hands of the Nazis," a kind of resistance. On the other, the image could be a commentary on his relationship with the Nazis-he cannot simply wash his hands of the cultural morass he inhabits, the "raw sewage" that is Nazi Germany.

Furtwängler used his art to survive, but it was not enough to express resistance. Ronald Harwood's lifelong friend, Harold Pinter, wrote about the difference between artistic and political language in his 2005 Nobel Prize speech. There he argued that truth in drama (and I think this may be expanded to all art) is "forever elusive. You never quite find it but the search for it is compulsive ... . More often than not you stumble upon the truth in the dark, colliding with it or just glimpsing an image or shape which seems to correspond to the truth, often without realizing that you have done so" (Pinter 2006, p. 1). However, political language and action require direct statements: "I believe that despite the enormous odds which exist, unflinching, unswerving, fierce intellectual determination, as citizens, to define the real truth of our lives and our societies is a crucial obligation which devolves upon us all. It is in fact mandatory" (Pinter 2006, p. 13). In other words, art suggests, but politics demands.

Taking Sides clearly illustrates the difficulties with making art under a totalitarian regime, making moral judgments and decisions, particularly on the part of artists accustomed to subtle, suggestive, and indirect means of expression. Under such conditions, their artistic means of communication are not powerful enough to stem the tide of dictatorship. Neither a handshake nor a handkerchief can save lives. Furtwängler admits that he was naive, but he also did not refuse the benefits from the Nazis. He remained to play his music, and he misjudged how Nazis would use that music. Taking Sides illustrates that any decision will leave something unaccounted for, a trace of the road not taken. Arnold's decision to call the journalist to make trouble for Furtwängler is not ideal behavior, but he does make a call. He takes a stand. He takes a side that, to use Pinter's concluding words to his Nobel Prize speech, shows a "determination" without which "we have no hope of restoring what is so nearly lost to us - the dignity of man" (Pinter 2006, p. 13). Furtwängler did not "take sides" or did not make his resistance clear enough. In the face of genocide, he chose a baton and handkerchief, not a call to action.

Funding: This research received no external funding.

Conflicts of Interest: The author declares no conflict of interest.

\section{References}

Aristotle. 1981. Aristotle's Poetics: A Translation and Commentary for Students of Literature. Translated by Leon Golden. Edited by O. B. Hardison Jr. Tallahassee: University Presses of Florida.

Bushnell, Rebecca. 2005. A Companion to Tragedy. Oxford: Blackwell. 
Canby, Vincent. 1996. Shining a Light on the Mind of a Genius. The New York Times, October 27, 5.

Cunningham, John. 2014. The Cinema of István Szabó: Visions of Europe. New York: Columbia University Press.

Dumling, Albrecht. 2002. The Target of Racial Purity: The 'Degenerate Music' Exhibition in Dusseldorf, 1938. In Art, Culture, and Media Under the Third Reich. Edited by Etlin Richard. Chicago: University of Chicago Press, pp. 43-47.

Eagleton, Terry. 2003. Sweet Violence: The Idea of the Tragic. Oxford: Blackwell.

Etlin, Richard. 2002. Introduction: The Perverse Logic of Nazi Thought. In Art, Culture, and Media Under the Third Reich. Edited by Richard Etlin. Chicago: University of Chicago Press, pp. 1-43.

Felski, Rita. 2008. Introduction. In Rethinking Tragedy. Edited by Rita Felski. Baltimore: Johns Hopkins University Press, pp. 21-28.

Foley, Helene P., and Jean E. Howard. 2014. Introduction: The Urgency of Tragedy Now. PMLA: Special Topic: Tragedy 129: 617-34. [CrossRef]

Gardiner, John. 2010. István Szabó's Taking Sides (2001) and the Denazification of Wilhelm Furtwängler. Historical Journal of Film, Radio, and Television 30: 95-109. [CrossRef]

Harwood, Ronald. 1980. The Dresser. In Collected Plays of Ronald Harwood. London: Faber and Faber, pp. 63-138.

Harwood, Ronald. 1983. The Dresser. Culver City, California, USA: Columbia Pictures.

Harwood, Ronald. 1995a. Introduction. In Ronald Harwood: Plays 2. London: Faber and Faber, pp. vii-xi.

Harwood, Ronald. 1995b. Taking Sides. In Ronald Harwood: Plays 2. London: Faber and Faber, pp. 1-67.

Harwood, Ronald. 2002. Taking Sides: The Screenplay. In The Pianist and Taking Sides. London: Faber and Faber, pp. 117-95.

Harwood, Ronald. 2005. Truth and Fiction: The Holocaust on Stage and Screen. European Judaism: A Journal for the New Europe 38: 4-16. [CrossRef]

Heilman, Robert Bechtold. 1968. Tragedy and Melodrama: Versions of Experience. Seattle: University of Washington Press.

Kater, Michael H. 2019. Culture in Nazi Germany. New Haven: Yale University Press.

Kauffman, Stanley. 2003. The Past Returning: Taking Sides. New Republic. 229: 30-31.

Pinter, Harold. 2006. Art, Truth, and Politics: Nobel Prize Speech. In The Essential Pinter: Selections from the Work of Harold Pinter. New York: Grove, pp. 1-13.

Robinson, W. Sydney. 2017. "Speak Well of Me": Ronald Harwood: The Authorized Biography. London: Oberon Books. Stewart, Victoria. 2000. Dramatic Justice?: The Aftermath of the Holocaust in Ronald Harwood's Taking Sides and The Handyman. Modern Drama 42: 1-12. [CrossRef]

Wallace, Jennifer. 2007. The Cambridge Companion to Tragedy. Cambridge: Cambridge University Press. 